\title{
Factors Driving the Intention to Pursue Internal Auditing Certification and Career among Future Graduates in Malaysia
}

\author{
Azleen Ilias ${ }^{1, *}$, Nasrudin Baidi ${ }^{1}$, Erlane K Ghani ${ }^{2}$, Rahida Abdul Rahman ${ }^{3}$ \\ ${ }^{1}$ College of Business and Administration, Universiti Tenaga Nasional, Malaysia \\ ${ }^{2}$ Faculty of Accountancy, Universiti Teknologi MARA Selangor, Malaysia \\ ${ }^{3}$ Labuan Faculty of International Finance, Universiti Malaysia Sabah, Malaysia
}

Received August 30, 2021; Revised November 8, 2021; Accepted November 22, 2021

\begin{abstract}
Cite This Paper in the following Citation Styles
(a): [1] Azleen Ilias, Nasrudin Baidi, Erlane K Ghani, Rahida Abdul Rahman, "Factors Driving the Intention to Pursue Internal Auditing Certification and Career among Future Graduates in Malaysia," Universal Journal of Accounting and Finance, Vol. 10, No. 2, pp. 549 - 558, 2022. DOI: 10.13189/ujaf.2022.100219.
\end{abstract}

(b): Azleen Ilias, Nasrudin Baidi, Erlane K Ghani, Rahida Abdul Rahman (2022). Factors Driving the Intention to Pursue Internal Auditing Certification and Career among Future Graduates in Malaysia. Universal Journal of Accounting and Finance, 10(2), 549 - 558. DOI: 10.13189/ujaf.2022.100219.

Copyright $\odot 2022$ by authors, all rights reserved. Authors agree that this article remains permanently open access under the terms of the Creative Commons Attribution License 4.0 International License

\begin{abstract}
This study aimed to investigate the accounting students' awareness, interest, and intention to pursue the Certified Internal Auditor (CIA) qualification and career. This study examined the driving factors (attitude, social norms, and perceived behavioral control) on the intention to pursue the CIA. This study was based on the Theory of Planned Behavior (TPB) and utilized an online questionnaire to survey 243 accounting students from eleven (11) universities in Malaysia. It found that ACCA, CPA, and CIA are the main qualifications they intend to pursue. This finding showed that most accounting students are aware of the internal auditing (IA) certification. Based on the regression analysis, social norms and perceived behavioral control impact the students' intention to pursue the CIA and IA career. This study could help universities and the Institute of Internal Auditors Malaysia (IIAM) develop interest among accounting students to see the benefits of CIA and career in IA.
\end{abstract}

Keywords Theory of Planned Behavior, Professional Certification, Attitude, Social Norms, Perceived Behavioral Control, Accounting Students, Certified Internal Auditor, Malaysia

\section{Introduction}

In Malaysia, there are issues with professional accountants having any professional certificate. Based on [1] defined a professional accountant as "an accountant who holds professional accountant certification and, therefore, gets official professionalism recognition." Based on [2], the professional accounting market had expressed concern about the shortage of talented educational bodies in various countries, including Malaysia, producing graduates in accounting-related fields. There is also the probability that undergraduate accounting students would not continue in accounting areas as their career path [3].

Research identifying the intention of graduates to pursue professional certificates, particularly the CPA, ACCA, CIMA, and ICAEW, are plenty. These studies [e.g., [4], [5], [1], [6], [7]] showed that Malaysian accounting undergraduates do intend to pursue professional certificates. Apart from intention, there are various factors that could motivate graduates to further their studies with professional certificates ([4]; [8]). However, there are limited studies in Malaysia on the CIA certification and being professionally certified internal auditors as a career. [9] mentioned that the CIA is important to those planning to become internal auditors. CIA is the only internationally accepted designation for 
the internal auditors' career path. It demonstrates competence in areas such as risk, control, and information technology.

In addition, [1] found that CIA is the second top certification after Certified Public Accountant (CPA). Most past studies (e.g., [10]; [11]; [8]; and [12]) were concerned on how practitioners or future graduates plan to pursue professional certificates. However, they did not focus on the perspective of internal auditors. Nonetheless, there studies in Malaysia on internal auditing as the preferred career [13], the effectiveness of internal auditors among government-linked companies (GLCs) [11], and internal auditing in the government sector such as [14], [15], [16], [17] and [18].

Based on the review of prior research, there is a population gap. Some of these sub-populations were unexplored and under-researched. The sample of accounting students appears to be important and worthy of investigation in the context of professional qualifications and internal auditing career. An investigation of this group is important because there is a need to enhance the development of internal auditors. Furthermore, previous research had focused primarily on practitioners. Very little research was done on the internal auditing professional qualification and career. Based on the limited research, there is a need to improve internal auditing as the preferred career due to the establishment of internal auditing as a profession in Malaysia. Furthermore, the need to have internal auditors had been highlighted by the Securities Commissions Malaysia (SCM) and in the new Malaysian Code of Corporate Governance (MCCG) 2017. Therefore, this research explored the preference of being an internal auditor and pursuing CIA among Malaysian accounting graduates.

The remainder of this paper is structured as follows. The following section, Section 2, provides the literature review related to the certification and career. Section 3 outlines the research methodology. The findings of this study are presented in Section 4. The final section summarises and concludes this study.

\section{Literature Review and Hypotheses Development}

A large body of research had addressed the issues of the accounting profession. [1] noted that not every accounting student is interested in pursuing accounting as a career once they graduate. Studies have also shown that students may not choose to be in the accounting profession due to their interests. Several studies have argued that professional accounting bodies are facing limited accounting graduates pursuing professional certificates. One of the challenges the accounting profession faces is the limited growth in the number of graduates preferring to be in the accounting profession with professional certificates. [9] encouraged students to sit for at least one certification to help them become more marketable.

Several studies had examined career choices and professional qualifications in various disciplines, including accounting. These studies showed that students tend to choose professional qualifications due to subjective norms and perceived behavioral control [2]. Similarly, [19] noted that students choose accounting as a profession because of job security or stability, financial assistance, and grit personality. [20] revealed that salary and job opportunities are reasons for becoming accountants. Meanwhile, [12] found that quality motivation, social motivation, and career motivation are factors to pursuing professional qualifications. However, economic motivation shows no influence on the interest to take professional qualifications.

Based on study [8] showed that family members in the accounting profession motivate public accountant as a career choice, and that parents influence the students' decision to pursue professional qualifications. Additionally, [21] revealed that students' preferences and beliefs about accounting professional qualifications, academic major, and grade point average are significantly associated with their intentions to pursue a CPA qualification. [13] found that parental and peer influence, personal interests, and management training have led to choosing internal auditing as a career. According to [22], job security and stability, opportunities for advancements, and students' perceptions of the profession play a significant role in the accounting students' decision to pursue professional examinations.

Job market considerations, perceived Sharia accountants' ethics, and subjective norms all have a significant positive effect on accounting students' intentions to become Certified Sharia Accountants, according to [23]. [24] discovered that students' intentions to pursue an accounting major/career are influenced by their attitude and factors related to subjective norms. Students' preference for professional membership, as well as their job prospect beliefs, social beliefs, and capability beliefs, are all positively and significantly associated with their intention to pursue a professional qualification, according to [25]. In addition, positive attitudes toward a profession are frequently associated with students' intentions to pursue a career in that field. Subjective norms have been shown to have a statistically significant impact on Emiratis' intentions to enter the accounting profession [26]. Generally, [2] had proven that subjective norms and perceived behavioral control play an important role and contribute towards the intention to pursue professional accounting qualifications.

Many studies had identified various factors that impact the intention to pursue professional qualifications such as [2] and [3], but few focused on internal audit such as in study done by [11]. On the other hand, some studies have related professional qualifications to internal auditing (IA). 
Thus, the Theory of Planned Behaviour (TPB) is an important foundation in investigating the intention to pursue professional accounting qualifications, especially the CIA. In the context of this study, the TPB could explain how the students' behavior could influence their intention to pursue professional qualifications which related to attitudes, subjective norms and perceived behavioral control. These factors that directly influence intentions toward the behavior according to TPB. Therefore, the following hypotheses were developed to investigate the influence of attitudes, subjective norms, and perceived behavioral control on pursuing internal auditing (IA).

H1: Students' attitudes impact the intention to pursue a professional qualification in IA.

H2: Social norms of students impact the intention to pursue a professional qualification in IA.

H3: Students' perceived behavioral control impacts the intention to pursue a professional qualification in IA.

\section{Research Design}

\subsection{Sample Selection}

Table 1. Respondents' Characteristic

\begin{tabular}{|c|c|c|}
\hline \multicolumn{3}{|c|}{ University } \\
\hline UiTM & 34 & Percent \\
\hline UUM & 50 & 13.99 \\
\hline USM & 22 & 20.58 \\
\hline UM & 9 & 9.05 \\
\hline UPSI & 14 & 3.70 \\
\hline UMS & 3 & 5.76 \\
\hline UNITEN & 35 & 1.23 \\
\hline MSU & 25 & 14.40 \\
\hline UNIKL & 15 & 10.29 \\
\hline UTAR & 35 & 6.17 \\
\hline POLITEKNIK & 1 & 14.40 \\
\hline \multicolumn{3}{|c|}{ Gender } \\
\hline Female & 194 & 0.41 \\
\hline Male & 49 & 79.84 \\
\hline \multicolumn{3}{|c|}{ CGPA } \\
\hline $3.5-4.0$ & 86 & 20.16 \\
\hline $2.2-2.99$ & 107 & 35.39 \\
\hline
\end{tabular}

The targeted population was the final semester accounting students in the Malaysian public and private universities. The universities that volunteered to participate were UiTM, UUM, USM, UM, UPSI, UMS, UNITEN, MSU, UNIKL, UTAR, and Politeknik in total of 243 students. The students' accounting background enabled them to contribute feedback on the internal auditing career. This study focused on the final semester students because they would be considering their education development and career path. Furthermore, they had been exposed to most of the accounting, auditing, and internal auditing subjects. Thus, they would have a better understanding of their career choices. The statistics in Table 1 show the distribution of the respondents for this study. The table also shows that most respondents are females, and their cumulative grade point average (CGPA) is mostly 3.0-3.49.

\subsection{Research Instrument and Data Collection}

This study's research instrument was a digital questionnaire distributed to the accounting students through social media over four months from October 2020 until January 2021. The questionnaire was divided into sections A to G. Section A provided information on the students' profile, including university, gender, and latest academic results. Section B contained 16 statements to investigate the types of professional certifications they intend to pursue. The items were measured by the degree of interest ranging from ' 1 ' not at all interested to ' 5 ' very interested. Section C contained two statements designed to obtain the respondents' experience of taking internal audit subjects, future career interests, and awareness of internal auditing. The awareness was measured by the degree of awareness ranging from ' 1 ' fully not aware to ' 5 ' fully aware.

Section D contained four statements designed to obtain the respondents' attitude, with the degree of agreement from strongly agree (scored as 5) to strongly disagree (scored as 1). The statements were adopted from [2] and modified to suit this study. In Section E, there were three statements, also adopted from [2], to investigate subjective norms. Section $F$ had three statements adopted from [2] to investigate perceived behavioral control. Finally, Section $G$ contained five statements on the intention to pursue the CIA qualification. The items in sections $\mathrm{D}$ to $\mathrm{G}$ were measured using the five-point scale ranging from ' 1 ' strongly disagree to ' 5 ' strongly agree. All the items could be considered reliable and consistent with Cronbach's alphas of greater than or equal to 0.7 , as shown in Table 2.

\section{Results and Discussion}

\subsection{Descriptive Analysis on Interest in Professional Qualification}

Table 3 presents the interest in certification among future graduates. This study found that $74.42 \%$ have interest in ACCA, followed by $81.48 \%$ in CPA, $62.14 \%$ in 
CIA, $64.20 \%$ in tax certification, and $60.91 \%$ in ICAEW. These are the five main certifications of interest among future graduates. They are least interested in CISA, CRMA, and CAIA, as shown by the low mean scores (mean < 3.4). Thus, this finding provides insight to the professional accounting bodies on strategies to attract future graduates to pursue professional certificates. This finding is aligned with [1] that revealed that their respondents have a high interest in the CPA and CIA. According to study done [21] and [19] also showed that the majority of their respondents have the desire to pursue a CPA qualification, preferably ACCA, followed by CMA and CIMA. [25] highlighted that a professional qualification could provide a more valuable and respectable perception in job interviews.

Table 2. Reliability Analysis

\begin{tabular}{|c|c|c|c|}
\hline & Cronbach's Alpha & N of Items & Section \\
\hline Respondents' Profile & & & A \\
\hline Interest on Professional Certification & & & B \\
\hline Awareness on Career and Internal Auditing & & 4 & C \\
\hline Attitude towards being an Auditor & 0.6715 & 3 & E \\
\hline Subjective Norms & 0.8751 & 3 & F \\
\hline Perceived Behavioral Control & 0.7714 & 5 & G \\
\hline Intention & 0.7454 & & \\
\hline
\end{tabular}

Table 3. Interest on certifications

\begin{tabular}{|c|c|c|c|c|c|c|c|}
\hline & & NAI & NVI & $\mathbf{N}$ & SI & VI & \\
\hline & Type of certificates & 1 & 2 & 3 & 4 & 5 & Mean \\
\hline 1. & Association of Chartered Certified Accountants (ACCA) & 1 & 10 & 39 & 62 & 131 & 4.28 \\
\hline 2. & Certified Public Accountant (CPA) & 1 & 3 & 41 & 110 & 88 & 4.16 \\
\hline 3. & Certified Internal Auditor (CIA) & 4 & 12 & 76 & 83 & 68 & 3.82 \\
\hline 4. & Chartered Tax Professional Certification & 8 & 23 & 56 & 76 & 80 & 3.81 \\
\hline 5. & Institute of Chartered Accountants England and Wales (ICAEW) & 7 & 14 & 74 & 82 & 66 & 3.77 \\
\hline 6. & Certified Fraud Examiner (CFE) & 9 & 20 & 59 & 95 & 60 & 3.73 \\
\hline 7. & $\begin{array}{c}\text { Malaysian Institute of Public Accountants and Chartered Accountants of } \\
\text { Australia and New Zealand (MICPA-CAANZ) }\end{array}$ & 6 & 18 & 80 & 72 & 67 & 3.72 \\
\hline 8. & Certified Management Accountant (CMA) & 11 & 18 & 76 & 71 & 67 & 3.68 \\
\hline 9. & Chartered Financial Analyst (CFA) & 12 & 26 & 79 & 71 & 55 & 3.54 \\
\hline 10. & Anti-Money Laundering (AML) Specialist Certification & 14 & 23 & 83 & 63 & 60 & 3.54 \\
\hline 11. & Certified Financial Analyst (CFA) & 12 & 30 & 77 & 73 & 51 & 3.50 \\
\hline 12. & Chartered Banker Qualification & 12 & 31 & 87 & 65 & 48 & 3.44 \\
\hline 13. & Certificate in Internal Auditing for Financial Institutions (CIAFIN) & 11 & 33 & 94 & 58 & 47 & 3.40 \\
\hline 14. & Certified Information Systems Auditor (CISA) & 13 & 30 & 95 & 66 & 39 & 3.36 \\
\hline 15. & Certificate in Risk Management Assurance (CRMA) & 13 & 33 & 99 & 62 & 36 & 3.31 \\
\hline 16. & Chartered Alternative Investment Analyst (CAIA) & 18 & 45 & 88 & 57 & 35 & 3.19 \\
\hline
\end{tabular}

Key: NAI = Not at all interested, NVI = Not very interested, $\mathrm{N}=$ Neutral, $\mathrm{SI}=$ Somewhat interested, $\mathrm{VI}=$ Very interested 


\subsection{Descriptive Analysis of Accounting Students' Awareness}

Table $4 \mathrm{a}$ presents the statistics of the awareness of internal auditing. Among the 243 students, $72.02 \%$ had taken an internal auditing course in their formal education. This study showed that $39.09 \%$ are interested in becoming accountants, $19.75 \%$ external auditors, and $9.47 \%$ internal auditors. Table $4 \mathrm{~b}$ presents the awareness statistics specifically on internal auditing. The results show that, generally, the students are aware of the existence of the IIAM and the importance of a career in internal auditing and the CIA. However, most students are not aware of the development of practitioners that hold a professional qualification and the benefits of CIA and CRMA. They might be aware of the importance of these certifications but do not understand the benefits that they can gain from having both qualifications.

Table 4 (a). Experience in the IA Subject and Interest on IA Career

\begin{tabular}{|c|c|c|}
\hline & Frequency & Percent \\
\hline \multicolumn{3}{|c|}{ Have you taken an internal auditing subject? } \\
\hline Yes & 175 & 72.02 \\
\hline No & 68 & 27.98 \\
\hline \multicolumn{3}{|c|}{ What is your career interest in the future? } \\
\hline Internal Auditor & 23 & 9.47 \\
\hline Accountant & 95 & 39.09 \\
\hline External Auditor & 48 & 19.75 \\
\hline Banker & 7 & 2.88 \\
\hline Financial Analyst & 5 & 2.06 \\
\hline Accounts Executive & 21 & 8.64 \\
\hline Finance Executive & 5 & 2.06 \\
\hline Forensic Accountant & 12 & 4.94 \\
\hline Fraud Examiner/Investigator & 5 & 2.06 \\
\hline Others & 22 & 9.05 \\
\hline Total & 243 & 100 \\
\hline
\end{tabular}

Table 4 (b). Awareness on Internal Auditing

\begin{tabular}{|c|c|c|c|c|c|c|c|}
\hline & & FNA & NA & $\mathrm{N}$ & A & FA & \\
\hline & & 1 & 2 & 3 & 4 & 5 & Mean \\
\hline \multicolumn{8}{|c|}{ Accounting Students' Awareness } \\
\hline 1. & The existence of the Institute of Internal Auditors Malaysia & 2 & 14 & 38 & 84 & 105 & 4.14 \\
\hline 2. & $\begin{array}{c}\text { The importance of the professional qualification of Certified Internal } \\
\text { Auditor (CIA) }\end{array}$ & 2 & 5 & 41 & 90 & 105 & 4.20 \\
\hline 3. & $\begin{array}{l}\text { The insufficient numbers of Malaysian practitioners with professional } \\
\text { qualification in Malaysia }\end{array}$ & 9 & 33 & 65 & 88 & 48 & 3.55 \\
\hline 4. & The benefits of the Certified Internal Auditor (CIA) qualification & 7 & 24 & 54 & 91 & 67 & 3.77 \\
\hline 5. & The benefits of the Certificate in Risk Management Assurance (CRMA) & 10 & 44 & 78 & 73 & 38 & 3.35 \\
\hline 6. & The importance of Internal Audit career & 2 & 9 & 43 & 109 & 80 & 4.05 \\
\hline
\end{tabular}

Key: FNA = Fully not aware, NA = Not aware, $\mathrm{N}=$ Neutral, A = Aware, FA = Fully aware 


\subsection{Descriptive Analysis on Factors to Pursue Professional Qualification in IA}

Table 5 presents the statistics on attitudes, subjective norms, perceived behavioral control, and intention towards internal auditing among accounting students. For the attitude factor, the students believed that they could obtain a high salary with the CIA qualification, and they have a good perception of the qualification. They believed that the CIA opens possible promotion and other opportunities in the future. However, the students do not perceive salary as the main reason for choosing internal auditing. In relation to peer influence for choosing CIA, this study shows that students perceived the attraction comes from their lecturers. They are less influenced by friends and other important people. Relating to perceived behavioral control, the students perceived that the need to pursue the CIA depends on their own decision, followed by their own dream and confidence level to pursue the CIA. The high awareness of the CIA in this study aligned with [1], which found that the CIA is considered very important for individuals in internal auditing. This study also showed that, although the students are interested in a career as internal auditors, they are still unsure about IA as their first priority.

Table 5. Factors Driving the Intention to Pursue the CIA Professional Qualification

\begin{tabular}{|c|c|c|c|c|c|c|c|}
\hline & & SD & D & $\mathbf{N}$ & $\mathbf{A}$ & SA & \\
\hline & & 1 & 2 & 3 & 4 & 5 & Mean \\
\hline \multicolumn{8}{|c|}{ ATT } \\
\hline 1. & $\begin{array}{l}\text { Pursuing professional examination and qualification related to internal } \\
\text { auditing is good for me }\end{array}$ & 1 & 2 & 31 & 118 & 91 & 4.22 \\
\hline 2. & $\begin{array}{l}\text { I can gain a high salary if I have a professional qualification related to } \\
\text { internal auditing }\end{array}$ & 1 & 1 & 38 & 104 & 99 & 4.23 \\
\hline 3. & $\begin{array}{c}\text { The Certified of Internal Auditor qualification will provide better } \\
\text { opportunities for promotion/career }\end{array}$ & 3 & 0 & 43 & 115 & 82 & 4.12 \\
\hline 4. & Salary is the main factor in my career choice in internal auditing & 4 & 17 & 62 & 98 & 62 & 3.81 \\
\hline \multicolumn{8}{|c|}{ SN } \\
\hline 1. & $\begin{array}{c}\text { Most people important to me think that I should pursue a professional } \\
\text { qualification in internal auditing }\end{array}$ & 9 & 28 & 82 & 86 & 38 & 3.424 \\
\hline 2. & $\begin{array}{l}\text { My friends think that I should pursue a professional qualification in } \\
\text { internal auditing }\end{array}$ & 12 & 28 & 99 & 72 & 32 & 3.486 \\
\hline 3. & $\begin{array}{l}\text { My lecturers think that I should pursue a professional qualification in } \\
\text { internal auditing }\end{array}$ & 8 & 21 & 102 & 67 & 45 & 3.667 \\
\hline \multicolumn{8}{|c|}{ PBC } \\
\hline 1. & I am confident that I can be a certified internal auditor someday & 5 & 16 & 94 & 80 & 48 & 3.62 \\
\hline 2. & Pursuing to be a certified internal auditor is up to me & 1 & 2 & 51 & 101 & 88 & 4.12 \\
\hline 3. & $\begin{array}{l}\text { Pursuing a professional qualification will result in aspiring my dream to } \\
\text { be a certified internal auditor }\end{array}$ & 4 & 12 & 82 & 84 & 61 & 3.77 \\
\hline \multicolumn{8}{|c|}{ INT } \\
\hline 1. & $\begin{array}{l}\text { I will pursue the professional qualification to become a certified internal } \\
\text { auditor after graduating }\end{array}$ & 5 & 28 & 81 & 86 & 43 & 3.55 \\
\hline 2. & $\begin{array}{l}\text { The Certified Internal Auditor qualification will be my first priority in my } \\
\text { career choice }\end{array}$ & 14 & 36 & 105 & 56 & 32 & 3.23 \\
\hline 3. & A career as a certified internal auditor will be my interest & 4 & 5 & 57 & 88 & 89 & 4.04 \\
\hline 4. & It is not enough to have degree in accountancy to be an internal auditor & 6 & 16 & 71 & 95 & 55 & 3.73 \\
\hline 5. & $\begin{array}{l}\text { I like the challenges when taking professional examination related to } \\
\text { internal auditing }\end{array}$ & 5 & 20 & 87 & 81 & 50 & 3.62 \\
\hline
\end{tabular}

Key: $\mathrm{ATT}=$ attitude, $\mathrm{SN}=$ subjective norms, $\mathrm{PBC}=$ perceived behavioral control, $\mathrm{INT}=$ intention $\mathrm{SD}=$ Strongly Disagree, $\mathrm{D}=$ Disagree, $\mathrm{N}=$ Neutral, $\mathrm{A}=$ Agree, $\mathrm{SA}=$ Strongly Agree 


\subsection{Distribution Analysis of Factors to IA Pursue Professional Qualification}

Table 6 presents the mean, skewness, and kurtosis, which indicate the data distribution. This study showed skewness between +0.02 and -0.37 , while kurtosis was from 0.00 to -0.21 for each variable. Based on [27], a value of skewness and kurtosis between +2.0 and -2.0 is, in many cases, acceptable and consider normal distribution. Therefore, attitude, subjective norms, perceived behavioral control, and intention in this study are considered normally distributed.

Table 6. Descriptive Statistics for Factors Driving the Intention to Pursue the CIA Professional Certificate

\begin{tabular}{|c|c|c|c|}
\hline & Mean & Skewness & Kurtosis \\
\hline ATT & 4.10 & -0.27 & 0.66 \\
\hline SN & 3.44 & -0.37 & 0.08 \\
\hline PBC & 3.84 & -0.21 & 0.00 \\
\hline INT & 3.64 & 0.02 & -0.21 \\
\hline
\end{tabular}

Key: $\mathrm{ATT}=$ attitude, $\mathrm{SN}=$ subjective norms, $\mathrm{PBC}=$ perceived behavioral control, INT $=$ intention

\subsection{Correlation Analysis on Factors to Pursue Professional Qualification in IA}

Table 7. Correlation Analysis for Factors Driving the Intention to Pursue the CIA Professional Certificate

\begin{tabular}{|c|c|c|c|c|c|}
\hline \multicolumn{6}{|c|}{ Correlations } \\
\hline & & ATT & SN & PBC & INT \\
\hline \multirow{2}{*}{ ATT } & $\begin{array}{c}\text { Pearson } \\
\text { Correlation } \\
\end{array}$ & 1 & $.322^{* *}$ & $.398^{* *}$ & $.346^{* *}$ \\
\hline & Sig. (2-tailed) & & .000 & .000 & .000 \\
\hline \multirow{2}{*}{ SN } & $\begin{array}{c}\text { Pearson } \\
\text { Correlation } \\
\end{array}$ & & 1 & $.426^{* * *}$ & $.577^{* *}$ \\
\hline & Sig. (2-tailed) & & & .000 & .000 \\
\hline \multirow{2}{*}{$\mathrm{PBC}$} & $\begin{array}{c}\text { Pearson } \\
\text { Correlation } \\
\end{array}$ & & & 1 & $.688^{* *}$ \\
\hline & Sig. (2-tailed) & & & & .000 \\
\hline \multirow{2}{*}{ INT } & $\begin{array}{c}\text { Pearson } \\
\text { Correlation }\end{array}$ & & & & 1 \\
\hline & Sig. (2-tailed) & & & & \\
\hline
\end{tabular}

Key: $\mathrm{ATT}=$ attitude, $\mathrm{SN}=$ subjective norms, $\mathrm{PBC}=$ perceived behavioral control, INT= intention

The relationship between attitude, subjective norms, perceived behavioral control, and intention towards internal audits among accounting students was investigated using Pearson product-moment correlation coefficient. The results are shown in Table 7. Preliminary analyses were performed to ensure no violation of the assumptions of normality. Based on [28] a correlation (r) of 0 indicates no relationship at all, 0.5 to 1.0 indicates a high correlation, 0.3-0.49 indicates a moderate correlation, and 0.10-0.29 denotes a small correlation. The results in Table 7 shows a strong, positive correlation between PBC and INT $(\mathrm{r}=0.688, \mathrm{p}<0.000)$. There is also a high positive correlation between SN and INT $(r=0.577, p<$ $0.000)$. There is a moderate correlation between the ATT and PBC $(r=0.398, p<0.000)$, between the ATT and SN $(\mathrm{r}=0.322, \mathrm{p}<0.000)$ and between ATT and INT $(\mathrm{r}=$ $0.346, \mathrm{p}<.000)$.

\subsection{Regression Analysis on Factors to Pursue Professional Qualification on IA}

Table $8 \mathrm{a}$ shows the collinearity statistics of the variables in this study. Based on Table 8a, the tolerance values for ATT (0.813), SN (0.791), and PBC (0.743) are greater than 0.10 and well below the cut-off of 10 . Therefore, there is no violation of the multicollinearity assumption, as suggested by [29]. The VIF values also support the finding. Table $8 \mathrm{~b}$ shows the summary of the multiple regression results and the statistics of its overall fit. In the table, the $\mathrm{R} 2$ value shows that $57.3 \%$ of the variation in the intention to pursue the CIA qualification is explained by the variation of attitude, subjective norms, and perceived behavioral control. The F-test of the overall significance indicates whether the regression model provides a better fit than a model that contains no independent variables. Based on the F-value in Table 8c, the model is deemed significant $[\mathrm{F}(3,239)=106.756, \mathrm{p}<$ $0.000]$, implying a significant linear relationship with the intention to pursue the CIA qualification.

In Table 8a, the results show that attitude does not significantly influence the students' decision to pursue the CIA since the p-value is 0.615 , which is greater than 0.05 . Therefore, H1 is not supported as there is no significant linear relationship between the decision to pursue the CIA and attitude. This finding is aligned with [2], which found no influence of attitude on the intention to pursue any professional qualification. For $\mathrm{H} 2$ on social norms, the beta coefficient of 0.270 indicates a small positive relationship between social norms and the intention to pursue the CIA qualification, at $\mathrm{p}$-value $<0.000$. While for $\mathrm{H} 3$ perceived behavioral control, the table shows $\mathrm{B}=$ 0.509 , indicating a high positive relationship, at a p-value $<0.000$, between the intention to pursue the CIA qualification and perceived behavioral control. Therefore, $\mathrm{H} 2$ and $\mathrm{H} 3$ are supported. 
Table 8 (a). Coefficient

\begin{tabular}{|c|c|c|c|c|c|c|c|}
\hline & \multirow{2}{*}{ Model } & \multicolumn{2}{|c|}{ Unstandardized Coefficients } & \multirow{2}{*}{$\mathbf{t}$} & \multirow{2}{*}{ Sig. } & \multicolumn{2}{|c|}{ Collinearity Statistics } \\
\hline & & B & Std. Error & & & Tolerance & VIF \\
\hline \multirow{4}{*}{1} & (Constant) & .638 & .230 & 2.770 & .006 & & \\
\hline & ATT & .029 & .058 & .504 & .615 & .813 & 1.230 \\
\hline & SN & .270 & .037 & 7.206 & .000 & .791 & 1.264 \\
\hline & PBC & .509 & .047 & 10.863 & .000 & .743 & 1.346 \\
\hline
\end{tabular}

Table 8 (b). Model Summary

\begin{tabular}{|c|c|c|c|c|}
\hline Model & R & R-Square & Adjusted R-Square & $\begin{array}{c}\text { Std. Error of the } \\
\text { Estimate }\end{array}$ \\
\hline 1 & $.757^{\mathrm{a}}$ & .573 & .567 & .46587 \\
\hline
\end{tabular}

Key: $\mathrm{ATT}=$ attitude, $\mathrm{SN}=$ subjective norms, $\mathrm{PBC}=$ perceived behavioral control, $\mathrm{INT}=$ intention

Table 8 (c). ANOVA

\begin{tabular}{|l|c|c|c|c|c|c|}
\hline \multicolumn{2}{|c|}{ Model } & Sum of Squares & df & Mean Square & F & Sig. \\
\hline \multirow{3}{*}{1} & Regression & 69.510 & 3 & 23.170 & 106.756 & $.000^{\mathrm{b}}$ \\
\cline { 2 - 6 } & Residual & 51.872 & 239 & .217 & & \\
\cline { 2 - 6 } & Total & 121.382 & 242 & & \\
\hline \multicolumn{2}{l}{ a. Dependent Variable: INT } \\
\multicolumn{2}{|l}{ b. Predictors: (Constant), PBC, ATT, SN } \\
\hline
\end{tabular}

\section{Conclusions, Limitations and Future Research}

This study concluded that social norms and perceived behavioural control could influence the intention to pursue the CIA qualification. Hence, it is possible that friends and lecturers could encourage the students to become internal auditors and pursue the CIA qualification. However, the attitude among the students did not play an important role in influencing their intention to pursue the CIA qualification. Perceived behavioral control also affects the intention. A person might have varying perceptions of behavioral control depending on the situation of intention. [23] indicated that subjective norm is the most dominant factor influencing students' intention to become Certified Sharia Accountants. While, [24] found that attitude from personal interests, perception of accounting education, and subjective norms (influence of instructor and social influence of family and peers) impact the intention to major in accounting. This study is different from [25], which found a significant positive relationship between job belief, social belief, capability belief, preference, and the students' intention to pursue professional qualifications. Earlier, [19] found that job security or stability, financial assistance, and grit personality were the most important factors for pursuing professional qualifications and career. Other than the above finding, this current study also showed that students do have interests in various professional certifications. However, its focus was on the internal auditing career and certification. Most students in this study have basic knowledge in internal auditing subject.

This study was limited to the final semester accounting students selected at random from public and private universities in Malaysia. Future studies may focus on a specific university that offers internal auditing courses. Their results might lead to a better understanding of the perception of internal auditing among students. Another limitation of this study is the focus on three drivers from the TPB: attitude, social norms, and perceived behavioral control. Future studies might look at other driving factors identified by past studies that are important for pursuing professional qualifications. Despite the limitations, this study could provide insights into the strategies for attracting future graduates to pursue professional certifications in internal auditing and risk management, especially the CIA, to meet the need of the practitioners ([30]; [31]; [32]).

\section{Acknowledgements}

We wish to thank the Universiti Tenaga Nasional Malaysia for IRMC PUBLICATION FUND for their 
support and funding

\section{REFERENCES}

[1] Srirejeki, K., Faturahman, A., \& Supeno, S. (2019, May). 'Accounting certifications: Are students aware?', In 1st International Conference on Economics, Business, Entrepreneurship, and Finance (ICEBEF 2018), Atlantis Press, pp.655-658.

[2] Ishak, W.M. W, \& Padeli, W. (2019). 'Students'intention To Pursue Professional Qualification In Accounting: A Study Based On The Theory Of Planned Behaviour', International Conference on Global Education VII, Humanising Technology For IR 4.0, pp.492-501.

[3] Samsuri, A. S. B., Arifin, T. R. B. T., \& Hussin, S. B. (2016). 'Perception of undergraduate accounting students towards professional accounting career', International Journal of Academic Research in Accounting, Finance and Management Sciences, Vol. 6, No. 3, pp.78-88.

[4] Bahari, A. B. M., Tahir, W. M. M. W., \& Rahim, N. M. (2014). 'Student's intention and perception towards pursuing advanced accounting program', Gading Journal for the Social Sciences (e-ISSN 2600-7568), Vol. 18, No.2, pp.1-17.

[5] Saat, M.M, Ismail, A.A., Jamal, N.M., Idris, N. \& Ramakrishnan, S. (2018). 'The Intention of Accounting Students in Pursuing Professional Qualification', International Journal of Engineering \& Technology, Vol. 7, No.3.21,pp.135-138

[6] Amaning, N., Anim, R. O., Kyere, A., \& Peprah-Amankona, G. (2020). 'Determinants of career intentions of accounting students', International Business Research, Vol. 13, No.12, pp.1-14.

[7] Amaning, N., Wahab, B. A., \& Morhe, O. O. (2021). 'Investigating the effect of effective factors determining the job of accounting students', Electronic Business, Vol. 20, No.1, pp. 48-58.

[8] Ibrahim, S. N. S., Pauzi, N. F. M., Shamsudin, A., Karim, M. S., \& Ahmad, K. (2017). 'Motivating Factors for Sustainable Accountant Potentials in Malaysia', In SHS Web of Conferences, EDP Sciences, Vol. 36, pp. 00035.

[9] Dean, P., Bare, K., \& Wiseman, T. (2019). 'Are certifications necessary to join the C-Suite?', International Journal of Business and Social Science, Vol. 10, No.7, pp.10-13.

[10] Hamid, S. A. (2017). 'Motivations to Pursue Professional Accounting Qualifications Among Accounting Undergraduates in Malaysia', In Proceeding of the 4 th International Conference on Management and Muamalah, pp. 674-683.

[11] Nazri, S. N. F. S. M., Rasib, M. I. A., \& Zolkifli, S. (2019). 'The influence of competency, usage of it, and career expectation on internal auditor's effectiveness in Government Linked Companies (GLCs)', International Journal of Financial Research, Vol. 10, No. 3, pp.337-352.
[12] Ulfah, R., Jaharadak, A., \& Khatibi, A. (2019). 'Motivational factors influencing MSU accounting students to become a certified public accountant (CPA)', Management Science Letters, Vol. 9, No. 10, pp.675-1684.

[13] Shan, T. Y., Rou, W. J., \& Nair, R. K. (2019, August). 'Factors influencing acounting students in UCSI in choosing internal audit as their career options', In Proceedings of the 2019 2nd International Conference on E-Business, Information Management and Computer Science, pp.1-5.

[14] Yusof, N. A. Z. M., Haron, H., \& Ismail, I. (2016). 'Internal Audit Practice in Malaysian Public Sector Organizations', The National Conference for Postgraduate Research, pp. 120-126.

[15] Eshiet, U. E. (2017). 'Implications of Accountants Unethical Behavior and Corporate Failures', International Journal of Business, Economics and Management, Vol.4, No. 4, 82-94.

[16] Mejdoub, H., \& Arab, M. B. (2017). 'A Multivariate Analysis for Risk Capital Estimation in Insurance Industry: Vine Copulas', Asian Development Policy Review, Vol. 5, No. 2, pp.100-119.

[17] Oitsile, B., Galebotswe, O., \& Sekwati, L. (2018). 'Insurance-Economic Growth Nexus: Evidence from Botswana', Asian Economic and Financial Review, Vol. 8, No. 6,pp. 843-852.

[18] Changeeach, J. K. (2018). 'An Historical Trajectory of the Economic Transformation of the Southern Keiyo Community in Kenya', Global Journal of Social Sciences Studies, Vol. 4, No.2, pp. 52-69.

[19] Aziz, D. A., Ibrahim, M. A., Sidik, M. H. J., \& Tajuddin, M. (2017). 'Accounting students' perception and their intention to become professionally qualified accountants', In SHS Web of Conferences, Vol. 36, No. 8, EDP Sciences.

[20] Omar, S.A., Hasbolah, F. \& Yusof, K. (2019). 'Awareness, Perception And Behaviour Of Accounting Students In Private Higher Education Institution Towards Professional Accountancy Qualifications', International Journal of Accounting, Finance and Business (IJAFB). Vol. 4, No. 20, pp. $116-128$.

[21] Owusu, G. M. Y., Obeng, V. A., Ofori, C. G., Kwakye, T. O., \& Bekoe, R. A. (2018). 'What explains student's intentions to pursue a certified professional accountancy qualification?', Meditari Accountancy Research, Vol.26, No.2, pp. 284-304, https://doi.org/10.1108/MEDAR-06-20 16-0065.

[22] Mustapha, M., \& Hassan, M. H. A. (2012). 'Accounting Students' Perception on Pursuing Professional Examination', International Journal of Education, Vol. 4, No. 4, pp.1.

[23] Kholid, M. N., Tumewang, Y. K., \& Salsabilla, S. (2020). 'Understanding students' choice of becoming Certified Sharia Accountant in Indonesia', The Journal of Asian Finance, Economics, and Business, Vol. 7, No.10, pp.219-230.

[24] Awadallah, E., \& Elgharbawy, A. (2021). 'Utilizing the theory of reasoned action in understanding students' choice in selecting accounting as a major', Accounting Education, Vol. 30, No. 1, pp. 86-106. 
[25] Hashim, H. H. N., \& Ghani, E. K. (2020). 'Belief, preference and constraint factors influencing Malaysian accounting students' intention to pursue professional qualification', Universal Journal of Educational Research, Vol.8, No.3, pp.1078-1091.

[26] Hammour, H. (2018). 'Influence of the attitudes of Emirati students on their choice of accounting as a profession', Accounting Education, Vol. 27, No. 4, pp. 433-451.

[27] George, D., \& Mallery, P. (2019). IBM SPSS statistics 26 step by step: A simple guide and reference. Routledge.

[28] Cohen, J. (1988). Statistical power analysis for the behavioral sciences. Lawrence Erlbaum Associates.

[29] Pallant, J. (2020). SPSS survival manual: A step by step guide to data analysis using IBM SPSS. Routledge.

[30] Iyer, V. (2016). CAE Career Paths. Characteristics and Competencies of Today's Internal Audit Leaders. The IIA Research Foundation. Florida, USA.

[31] Vadasi, C., Bekiaris, M., \& Andrikopoulos, A. (2019). 'Corporate governance and internal audit: An institutional theory perspective. Corporate Governance', The International Journal of Business in Society, Vol. 20, No. 1 , pp.175-19

[32] Plant, K., Barac, K., \& Sarens, G. (2019). 'Preparing work-ready graduates-skills development lessons learnt from internal audit practice', Journal of Accounting Education, Vol.48, pp.33-47. 